\title{
Effect of lining application techniques on microleakage in class II composite restorations
}

\author{
Byung-Moon Hwang', Joo-Hyung Kim², Ji-Man Park1, Philip Millstein³, Eun-Jin Park* \\ 'Department of Dentistry, School of Medicine, Ewha Womans University, Seoul, Republic of Korea \\ ${ }^{2}$ Department of Prosthodontics, School of Dentistry, Seoul National University, Seoul, Republic of Korea \\ ${ }^{3}$ Division of Biomaterials and Prosthodontics, Harvard School of Dental Medicine, Boston, USA
}

Purpose: The purpose of this study was to investigate the microleakage in class II cavity resin restorations used with resin-modified glass ionomer (RMGI) lining material depending on two different applying methods; classical delivery method using a dental explorer and a specially designed rotating bur. Materials and Methods: A total thirty-six extracted teeth were prepared with a class II proximal box, and randomly divided into three groups: 1) control group with no lining added and the proximal box restored (Group I), 2) the second group used RMGI as a lining material which was spread with an explorer (Group II), 3) the third group used a specially designed rotating bur to thin out RMGI (Group III). All teeth were restored with the same manner using incrementally placed resin composite. All 36 teeth were prepared and sectioned for the dye penetration test, and observed with a stereomicroscope for scoring the dye penetration. Results: When RMGI liners were used, both groups using an explorer and the special bur with the liner had significantly less microleakage than the control group with no liner $(P<0.05)$. The $50 \%$ of the group with RMGI liner using the bur showed no microleakage under a dye penetration test whereas all the teeth in control group showed microleakage of different degrees. However, there was no statistically significant difference between Group II and Group III. Conclusion: RMGI is an effective lining material to decrease microleakage in class II composite resin restorations regardless of applying methods. (J Dent Rehabil Appl Sci 2014;30(2):145-51)

Key words: composite resins; glass ionomer cements; dental leakage; dental cavity preparation

\section{Introduction}

The physical properties of resin composites have improved over the last decades. ${ }^{1}$ Though resin composites are used as alternatives to amalgam, there are many advantages of resin composite over amalgam; it exhibits a similar wear pattern, it is of equal strength and it does not contain mercury. ${ }^{2,3}$ In addition, cavity preparations for resin composites are more conservative than that for amalgam.

*Correspondence to: Eun-Jin Park, DDS, PhD

Department of Dentistry, School of Medicine, Ewha Womans University 911-1, Mok-6-dong, Yangchun-gu, Seoul, 158-710, Republic of Korea Tel: +82-2-2650-5042, Fax: +82-2-2650-5764, E-mail: prosth@ewha.ac.kr Received: February 20, 2014/Last Revision: April 15, 2014/Accepted: April 20, 2014
Like all restorations, resin composites have problems with interfacial bonding and the existence of voids between the cavity wall and restoration. ${ }^{4,5}$ Interfacial debonding is known to be caused by moisture contamination, ${ }^{6}$ polymerization shrinkage and a high modulus of elasticity when resin composites are cured. ${ }^{7}$ Voids are caused by viscosity which makes it difficult for resin composites to adapt to cavity margins. It is not easy to adapt resin composites to gingival margins, particularly if the margins are below

Copyright(C 2014 The Korean Academy of Stomatognathic Function and Occlusion. (c) It is identical to Creative Commons Non-Commercial License. 
the cemento-enamel junction. ${ }^{8}$ Restorations with marginal microleakage may develop marginal discoloration, secondary caries, hypersensitivity, and even pulp stimulation. ${ }^{8,9}$ Marginal microleakage is one of the most important causes of restoration failure. The less the microleakage, the better the prognosis.

Kasraei et al. showed that there was no significant difference between the self-etching system and the total-etching system in microleakage. ${ }^{10}$ Several incremental techniques have been suggested to reduce polymerization shrinkage of resin restoration such as horizontal incremental, oblique incremental, and centripetal incremental techniques, however, there is still procedural controversy. Gallo et al. reported no significant advantage with incremental technique, ${ }^{11}$ and on the other hand, Roopa et al. reported that the incremental technique was more useful than the bulk technique. ${ }^{12}$

Since a flowable lining is effective in decreasing microleakage and void for class II restorations, ${ }^{10,13,14}$ flowable resin or resin modified glass ionomer has been used for lining procedures. Kasraei et al. reported that resin-modified glass ionomer is more effective to reduce microleakge than flowable resin. ${ }^{10}$

However, delivering or spreading the lining materials is very technique sensitive and it is not easy to apply the lining consistently. An explorer has been generally utilized to apply the lining material. Resinmodified glass ionomer is too tacky to apply lining material uniformly. Millstein performed consistent and uniform lining using a specially designed bur in a plastic mold. ${ }^{15}$ However, it is unknown whether microleakage was altered. Therefore, the purpose of this study was to evaluate the usefulness of a resinmodified glass ionomer lining material for reducing microleakage in class II resin composite restoration especially applied using specially designed bur when compared with liner using an explorer.

\section{Materials and Methods}

\section{Tooth selection and cavity preparation}

Under IRB approval (No. 12-22A-16, Ewha Womans University Medical Center), thirty-six intact

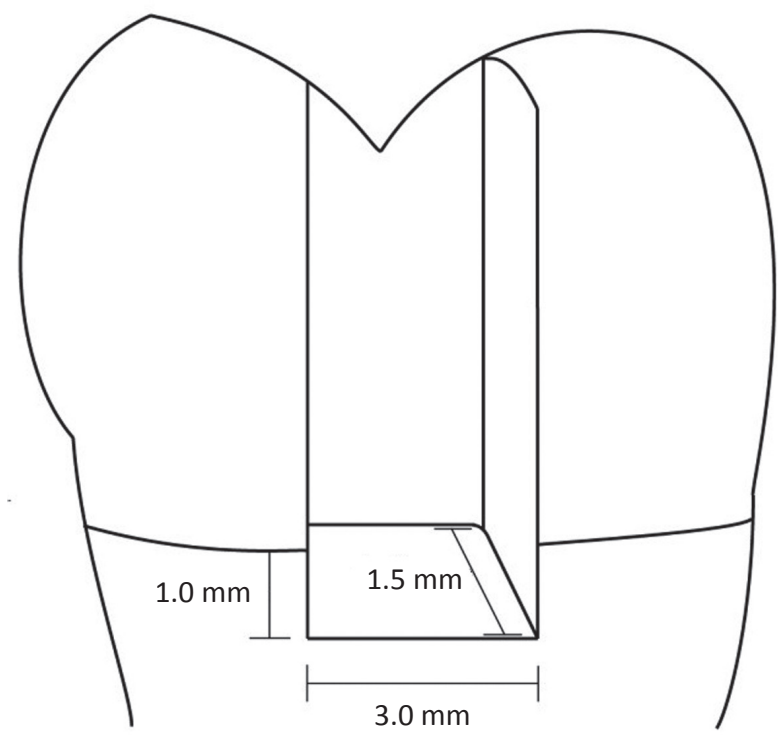

Fig. 1. Schematic view of the tooth preparation.

human teeth (premolars, 1st molars, 2nd molars, and the third molars) extracted for periodontal or orthodontic reason were selected for this study. The teeth were stored in distilled water after cleansing with scalers prior to preparation. The teeth were prepared for one class II box-only cavity on the mesial or distal surface of each tooth using a high-speed hand piece with diamond bur under air-water spray (959KR-018, Komet, Berlin, Germany) as shown in Fig. 1. A periodontal probe was used for measurement of the preparation. All teeth were prepared by a single operator. The teeth were randomly divided into three groups with 12 teeth in each group and restored by the same operator.

\section{Restorations}

Group I: The cavities were etched with 35\% phosphoric acid gel for 15 seconds, rinsed thoroughly for 10 seconds, and blot dried with a foam pellet. Dentin wetting agent (AQUA-PREP F, Bisco, Schaumburg, IL, USA) and the 5th generation bond system (ONESTEP, Bisco) were applied with a nylon-bristled brush, as per the manufacturer's instructions. Light curing was done using an LED (Elipar FreeLight 2, 3M ESPE, St. Paul, MN, USA) with a light intensity 
of $1000 \mathrm{~mW} / \mathrm{cm}^{2}$. A second layer of ONE-STEP was applied in the same manner. Celluloid matrices were applied, and an oblique incremental technique was applied to place resin composite (Tetric NCeram, Ivoclar vivadent, Schaan, Liechtenstein) as shown in Fig. 2. Each layer was cured separately for 40 seconds. After the restorations were completed, extra thin discs of Sof-Lex (3M ESPE) were used to finish the margins except for gingival margins. The teeth were stored in distilled water before thermocycling.

Group II: The bonding steps were the same as in group I. Prior to placing resin composite, a resinmodified glass ionomer liner (Ionoseal, Bisco) of a $0.6-0.8 \mathrm{~mm}$ thickness was applied with an explorer. A side-to-side and up-and-down motion was used. Following this step, the resin-modified glass ionomer liner was light-cured for 20 seconds. The restoration procedure was the same as in group I.

Group III: The bonding steps were the same as group 1. For applying the resin-modified glass ionomer liner, the rotating bur was used instead of an explorer in the same manner for the same amount of time in group II. The bur used in this study is shown in Fig. 3. This special round bur was made of stainless steel, and $1.5 \mathrm{~mm}$ in diameter (Maillefler/

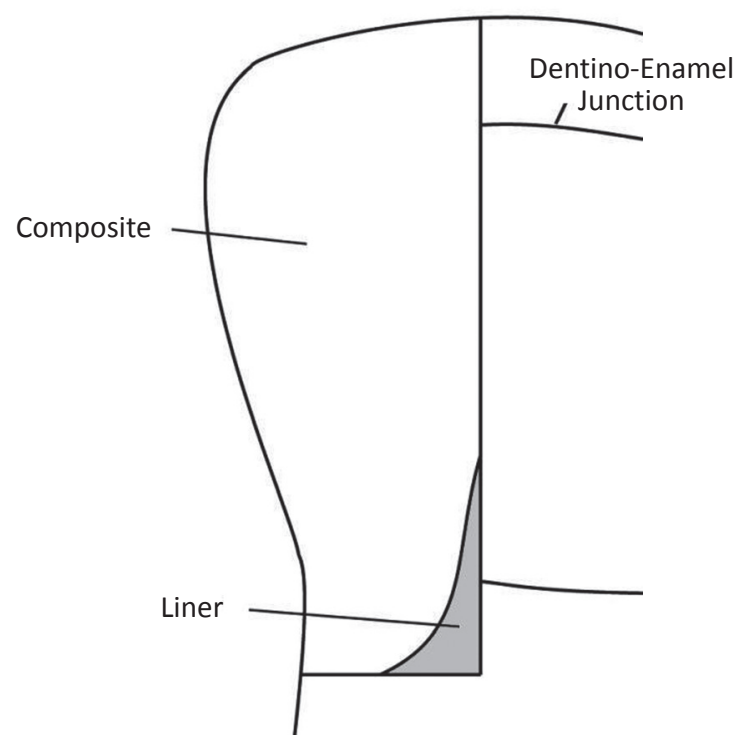

Fig. 2. Schematic view of liner placement for the closed sandwich technique.
Dentsply, Tulsa, OK, USA). It was made with a 5 degree bend in its shank so that it oscillated upon rotation. When the bur on a mass of composite rotates, it induces displacement oscillations on the composite surface at double speed of rotation. ${ }^{15}$ The speed of the bur was set at $300-500 \mathrm{rpm}$ for each cavity, and the restoration procedure after this step was the same as in group I.

\section{Thermocycling procedure}

Thermocycling was performed at $5^{\circ} \mathrm{C}-55^{\circ} \mathrm{C}$ for 1,000 cycles with a dwell time of 30 seconds. The teeth were painted with two coats of fingernail varnish, extending $1 \mathrm{~mm}$ beyond the margins of the restoration. The apex of the coated teeth was sealed with utility wax.

\section{Dye immersion}

Following thermocycling, the teeth were immersed in $2 \%$ methylene blue at $37^{\circ} \mathrm{C}$ for 48 hours. The teeth were then rinsed with water and stored in distilled water prior to sectioning

\section{Sectioning}

Each tooth was sectioned mesiodistally through the center of the restoration using a diamond disk (918PB, Komet, Berlin, Germany) in the laboratory handpiece.

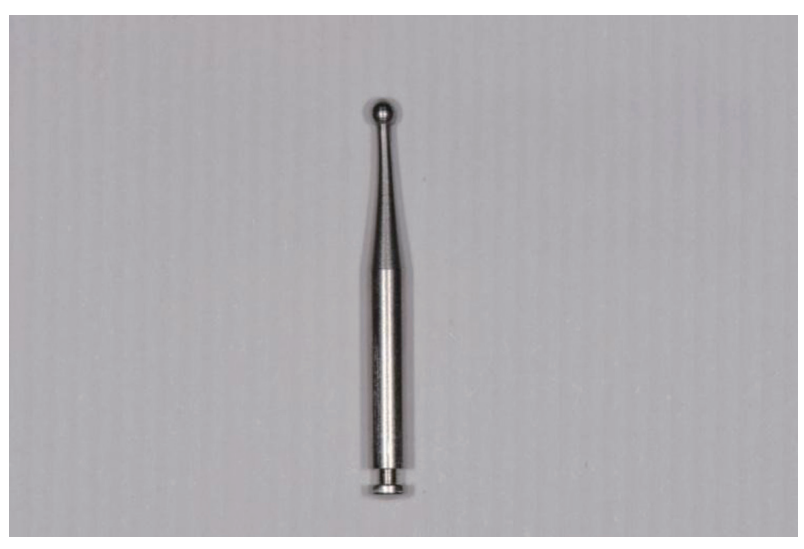

Fig. 3. The bur used in this study. 


\section{Dye penetration evaluation}

Each sectioned tooth was observed with a stereomicroscope (Fig. 4) and scored for the degree of dye penetration. Scoring was done by the operator who had no information as to which group each tooth belonged. The scoring scales borrowed from Kasraei et al. are shown in Fig. 5. ${ }^{10}$ The same examiner repeated scoring 24 hours later unaware of the previous score. The worst score was selected for compiling the final data.

\section{Statistical analysis}

The Kruskal-Wallis test was used to assess differences in the microleakage scores within the groups. If there were difference among groups, the Mann-Whitney U-test was used to investigate the pairwise differences among the groups. To avoid an accumulation of errors due to multiple comparisons, the significance level was modified dividing this $(P<0.05)$ by the number of comparison made (Bonferroni correction).
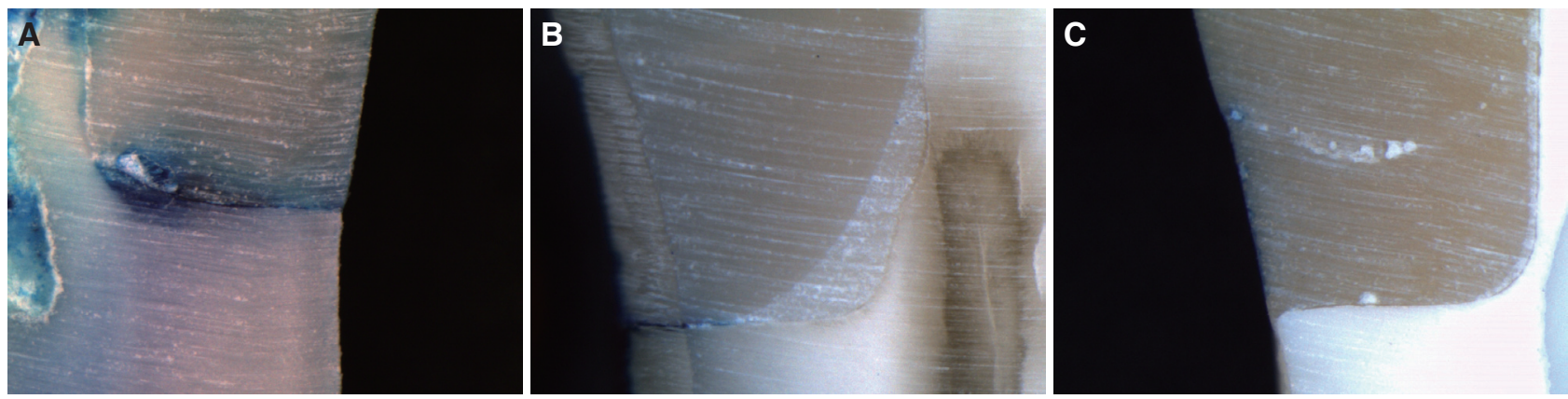

Fig. 4. Microleakage after staining with $2 \%$ methylene blue. (A) Control group, (B) RMGI LC liner using explorer, (C) RMGI LC liner using bur.

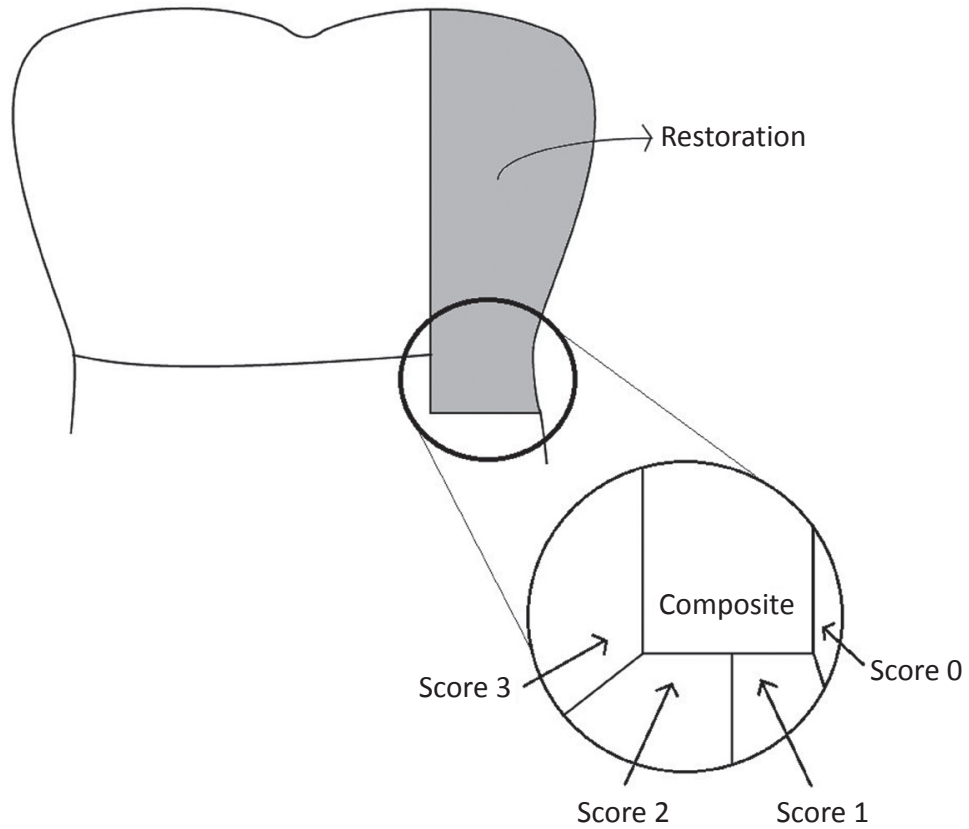

Fig. 5. Schematic view of the scoring scale for microleakage.

0 , no leakage; 1 , leakage extending to half of the cervical wall; 2 , leakage to the full extent of the cervical wall but not including the axial wall; 3 , leakage to the full extent of the cervical wall, including the axial wall. 


\section{Results}

Using a dye penetration test, we were able to obtain a microleakage score value (Table 1). There was no tooth that scored 0 in the control group for which no liner was applied. Using the Mann-Whitney Utest, Group I (No liner) and Group II (RMGI using explorer), and Group I and Group III (RMGI using bur) showed statistically significant $P$-value $(P=0.011$ and $P=0.016$ respectively). However, there was no statistically significant difference between Group II and Group III ( $P=0.902$, Table 2).

\section{Discussion}

As Kasraei et al. reported previously, ${ }^{10}$ our test showed a similar result of improving microleakage with the group using resin-modified glass ionomer as a lining material for the composite restoration. Not only was the number of teeth with a score 3 decreased in the group using RMGI compared to the group without the liner, there was also an increased number of teeth with a zero score. This result implies that the closed-sandwich technique improves microleakage not only between the surfaces of the RMGI and tooth but also between the surfaces of composite and tooth structure. ${ }^{16}$ This may have resulted from the stress-absorbing effect of RMGI layer with a low elastic modulus and the less shrinkage of composite in RMGI groups compared to the control group because RMGI probably replaced the space taken for the composite. ${ }^{17}$

In the previous study carried out by Kasraei et al., ${ }^{10}$ the group filling with RMGI and resin composite (Filtek P60, 3M ESPE) did not show any teeth with a score 3 in microleakge. In the current study, Group II and III were $16.67 \%$ and $25.00 \%$ in the percentage of a score 3 , respectively. This difference may come from the difference of bonding strength by combination of materials used for restoration.

We were not able to show statistically significant differences in microleakage between the group using the explorer and the group using the specially designed bur in this test. One of the reasons for this result may be a different lining configuration of RMGI in this study compared with that of a flowable composite as Millstein showed when using the bur. ${ }^{15}$ Another reason is that a certain level of lining RMGI may have an effect on polymerization shrinkage to decrease microleakage in the gingival wall of a restoration, regardless of lining RMGI uniformly. ${ }^{18}$ In other words, the important thing might be not how evenly the lining material is applied but what the area of contact between the resin composite and tooth structure is. The contact area between the resin composite and tooth structure is a half of the gingi-

Table 1. Microleakage scores

\begin{tabular}{lcccc}
\hline & Score 0 & Score 1 & Score 2 & Score 3 \\
& Number $(\%)$ & Number $(\%)$ & Number $(\%)$ & Number $(\%)$ \\
\hline Control group (I) & $0(0)$ & $3(25.00)$ & $2(16.67)$ & $7(58.33)$ \\
RMGI LC liner using explorer (II) & $5(41.67)$ & $3(25.00)$ & $2(16.67)$ & $2(16.67)$ \\
RMGI LC liner using bur (III) & $6(50.00)$ & $2(16.67)$ & $1(8.33)$ & $3(25.00)$ \\
\hline
\end{tabular}

RMGI, resin-modified glass-ionomoer; LC, light-cure.

Table 2. Comparison of microleakage among groups

\begin{tabular}{ccc}
\hline Groups & Groups & $P$-value \\
\hline No liner & RMGI LC liner using explorer & $0.011^{*}$ \\
No liner & RMGI LC liner using bur & $0.016^{*}$ \\
RMGI LC liner usign explorer & RMGI LC liner using bur & 0.902 \\
\hline
\end{tabular}

RMGI, resin-modified glass-ionomoer; LC, light-cure.

${ }^{a}$ Mann-Whitney U-tests

*denotes $P$-value is significant at 0.05 level. 
val wall of the restoration in this study.

Studies with flowable composite using the bur, a proper level of lining material and various contact areas between the resin composite and tooth structure in the gingival wall might be of further interest.

\section{Conclusion}

The effect of lining application techniques which was the usage of explorer or specially designed round bur on microleakage in class II composite restorations showed no statistically significant difference. However, RMGI is an effective lining material to decrease microleakage in class II composite resin restorations regardless of applying methods.

\section{References}

1. Ferracane JL. Resin composite-state of the art. Dent Mater 2011;27:29-38.

2. Opdam NJ, Bronkhorst EM, Roeters JM, Loomans BA. A retrospective clinical study on longevity of posterior composite and amalgam restorations. Dent Mater 2007;23:2-8.

3. Adams TC. A high-density posterior composite used for an amalgam replacement. Dent Today 1999;18:74-7.

4. Pamir T, Türkün M. Factors affecting microleakage of a packable resin composite: an in vitro study. Oper Dent 2005;30:338-45.

5. Roulet JF. The problems associated with substituting composite resins for amalgam: a status report on posterior composites. J Dent 1988;16:101-13.

6. Vicente A, Mena A, Ortiz AJ, Bravo LA. Water and saliva contamination effect on shear bond strength of brackets bonded with a moisture-tolerant light cure system. Angle Orthod 2009;79:127-32.

7. Gerdolle DA, Mortier E, Droz D. Microleakage and polymerization shrinkage of various polymer restorative materials. J Dent Child (Chic) 2008; 75:125-33.

8. Tredwin CJ, Stokes A, Moles DR. Influence of flowable liner and margin location on microleakage of conventional and packable class II resin composites. Oper Dent 2005;30:32-8.
9. Murray PE, Hafez AA, Smith AJ, Cox CF. Bacterial microleakage and pulp inflammation associated with various restorative materials. Dent Mater 2002;18:470-8.

10. Kasraei S, Azarsina M, Majidi S. In vitro comparison of microleakage of posterior resin composites with and without liner using two-step etch-andrinse and self-etch dentin adhesive systems. Oper Dent 2011;36:213-21.

11. Gallo JR 3rd, Bates ML, Burgess JO. Microleakage and adaptation of Class II packable resin-based composites using incremental or bulk filling techniques. Am J Dent 2000;13:205-8.

12. Nadig RR, Bugalia A, Usha G, Karthik J, Rao R, Vedhavathi B. Effect of four different placement techniques on marginal microleakage in class II composite restorations: an in vitro study. World J Dent 2011;2:111-16.

13. Guéders AM, Charpentier JF, Albert AI, Geerts SO. Microleakage after thermocycling of 4 etch and rinse and 3 self-etch adhesives with and without a flowable composite lining. Oper Dent 2006;31:450-5.

14. Kwon Y, Ferracane J, Lee IB. Effect of layering methods, composite type, and flowable liner on the polymerization shrinkage stress of light cured composites. Dent Mater 2012;28:801-9.

15. Abedian B, Millstein P. An effective method for spreading flowable composites in resin-based restorations. Oper Dent 2006;31:151-4.

16. Stockton LW, Tsang ST. Microleakage of Class II posterior composite restorations with gingival margins placed entirely within dentin. J Can Dent Assoc 2007;73:255.

17. Giachetti L, Scaminaci Russo D, Bambi C, Grandini R. A review of polymerization shrinkage stress: current techniques for posterior direct resin restorations. J Contemp Dent Pract 2006;7:79-88.

18. Choi KK, Condon JR, Ferracane JL. The effects of adhesive thickness on polymerization contraction stress of composite. J Dent Res 2000;79:812-7.

19. Jongsma LA, Kleverlaan CJ, Pallav P, Feilzer AJ. Influence of polymerization mode and $\mathrm{C}$-factor on cohesive strength of dual-cured resin cements. Dent Mater 2012;28:722-8. 


\section{다양한 방식으로 적용한 이장재가 2급와동 복합레진 수복의 미세누출에 미치는 영향}

황병문 ${ }^{1}$, 김주형 ${ }^{2}$, Philip Millstein ${ }^{3}$, 박지만 ${ }^{1}$, 박은진 ${ }^{1 *}$

${ }^{1}$ 이화여자대학교 의학전문대학원 치과학교실, ${ }^{2}$ 서울대학교 치의학대학원 치과보철학교실, ${ }^{3}$ 하버드치과대학교 생체재료보철학교실

목적: 본 연구는 두가지 다른 방법에 의한 레진강화형 글래스 아이오노머(RMGI) 이장재의 적용이 2급와동 복합레진 수복의 미세누출에 미치는 영향을 조사하고자 하였다.

연구 재료 및 방법: 36 개의 발치한 치아에 2 급 와동을 형성한 뒤 무작위로 3 개의 군으로 나누었다. 1 군은 대조군으로 이 장재를 적용하지 않았으며, 2 군은 치과용 탐침으로 RMGI 이장재 적용, 3 군은 특별히 고안된 버로 RMGI 이장재를 적 용한 뒤 복합레진은 똑같이 통상적인 방법으로 적층수복하였다. $2 \%$ 메틸렌 블루 염색한 뒤 치아장축과 평행하게 순설 방향으로 절단하여 미세누출을 현미경과 컴퓨터 프로그램을 사용하여 분석을 하였다. 데이터는 Kruskal-Wallis test와 Mann-Whitney U-test $(P<0.05)$ 로 분석하였다.

결과: RMGI 이장재가 적용된 군은 그렇지 않은 군보다 월등히 적은 미세누출을 보였으며, 특히 특수 고안된 버를 사 용한 군의 $50 \%$ 에서는 전혀 미세누출을 보이지 않았다. 그러나, 2 군과 3 군의 결과에서 통계적으로 유의한 차이는 관찰 되지 않았다.

결론: 2급와동의 복합레진 수복에서 RMGI 이장재는 그 적용 방법에 관계없이 미세누출을 감소시키는데 효과적인 재 료이다.

(구강회복응용과학지 2014;30(2):145-51)

주요어: 복합레진; 글래스아이오노머 시멘트; 미세누출; 2급와동

*교신저자: 박은진

(158-710) 서울 양천구 목동 911-1 이화여자대학교 의학전문대학원 치의학교실

Tel: 02-2650-5042 | Fax: 02-2650-5764 | E-mail: prosth@ewha. ac. kr

접수일: 2014년 2월 20일 | 수정일: 2014년 4월 15일 | 채택일: 2014년 4월 20일 